\title{
The effect of plant density on the yield of sweet potato
}

\author{
Adrienn Szarvas - Margit Szél Hódi - Tamás Monostori \\ Faculty of Agriculture, University of Szeged \\ 6800 Hódmezővásárhely, Andrássy 15, Hungary \\ szarvasadrienn@mgk.u-szeged.hu
}

\begin{abstract}
SUMMARY
A field study was conducted in South-East Hungary during the main cropping season of 2016, 2017 and 2018, with the objective of determining the effect of plant spacing on the productivity of sweet potato. Production technology experiments of four repetitions were set up in a randomized block design on sandy soil. The performed treatments consisted of four variations of plant spacing (row distance $x$ plant-to-plant distance): $80 \mathrm{~cm} \times 20 \mathrm{~cm}, 80 \mathrm{~cm} \times 30 \mathrm{~cm}, 100 \mathrm{~cm} \times 20 \mathrm{~cm}, 100 \mathrm{~cm} \times 30 \mathrm{~cm}$. The plant material was the Hungarian registered sweet potato variety 'Ásotthalmi-12'. Analysis of variance revealed that planting density significantly affected the average yield of storage roots. The highest yield per plant was achieved with the $100 \mathrm{~cm} \times 30 \mathrm{~cm}$ (2016, 2017), as well as with the $80 \mathrm{~cm} \times 30 \mathrm{~cm}$ (2018) setups. On hectare level, our results showed that the highest plant density of 62,500 plants ha ${ }^{-1}(80 \mathrm{~cm} \times 20 \mathrm{~cm}$ setup) could give the highest yield. Comparing the highest tons $\mathrm{ha}^{-1}$ results to those achieved with the plant spacing setups resulting in the highest yield per plant, the differences can be even 13 or 14 tons at hectare level. This finding underlines the importance of choosing the proper planting density towards the higher end.
\end{abstract}

Keywords: sweet potato, planting density, yield

\section{INTRODUCTION}

Batata or sweet potato (Ipomoea batatas (L.) Lam.) is a root crop of tropical-subtropical origin which is cultivated in the temperate zone, too. Along with several European countries, it has also been also grown in Hungary for decades, but the increase of its growing area was stimulated by the consumers' demand in the last couple of years.

Sweet potato is an important crop in many parts of the world. It is used not only as a staple food, but it is also an important industrial raw material for animal feed and alcohol production in different countries. Sweet potato is rich in secondary metabolites, especially antioxidant compounds including anthocyanins, carotenoids and vitamin C (Teow et al., 2007; Yoshinaga et al., 1999).

In Hungary, sweet potato is cultivated for more than thirty years (Horváth, 1991b,c). From the results of the experiments of Horváth (1991a) it was concluded that sweet potato can be successfully grown in our region. In Hungary, consumers' demands for sweet potato cannot be fulfilled even though the producers' interest is also intensively increasing. In spite of the published cultivation technology sheets and experiences, yield stability is still not solved, growing site- and genotypespecific advices are still missing.

In Hungary, the storage root yields range between 18 and $25 \mathrm{ha}^{-1}$, depending on the production site and the technology applied (http1). Sweet potato grows best where average temperatures are $20^{\circ} \mathrm{C}$. The crop can be damaged by frost, and this fact restricts the cultivation of sweet potato in the temperate regions to areas with a minimum frost-free period of 4-6 months (Negeve et al., 1992; Berényi and Szabó, 2001). According to Kay (1973), it grows best where the average temperature is $24{ }^{\circ} \mathrm{C}$. At temperatures below $10{ }^{\circ} \mathrm{C}$ its growth is severely retarded.
Singh and Singh (2002) explained that the establishment of an optimum population per unit area of the field is essential to get maximum yield. Therefore, the optimum plant population of individual crops should be worked out under suitable environmental conditions. Norman (1963) described that both too narrow and too wide spacing do affect yields through competition (for nutrients, moisture, air, radiation, etc) due to the inefficient utilization of the growth factors. A number of factors also influence spacing: fertility status of the soil, moisture availability, growth pattern of the crop and cultural practices.

The row distance generally applied in sweet potato production is between 70 and $107 \mathrm{~cm}$, the most preferred being $100 \mathrm{~cm}$. The usual plant-to-plant distance is 17 to $30 \mathrm{~cm}$, with $30 \mathrm{~cm}$ being most widely used (Bavec and Bavec, 2006; Clark, 2013; http2).

Recommended plant spacing for sweet potato in different countries are: $30-40 \mathrm{~cm}$ within the row by $102-112 \mathrm{~cm}$ between the rows in Ontario (OMAFRA, 2010), 25-36 cm by 91-122 cm in Kentucky (Coolong et al., 2012) or $25-30 \mathrm{~cm}$ by $81-107 \mathrm{~cm}$ in North Carolina (NCSPC, 2015). These correspond to planting densities of about 22,000 to almost 50,000 plants per hectare.

The planting density in sweet potato is a major factor that influences growth and yield (Onunka and Nwokocha, 2003).

Hence, evaluation of different planting densities is pertinent to improve the production and productivity of the crop. Therefore, this research was conducted to determine the effect of planting density on the growth and yield of one sweet potato cultivar. 


\section{MATERIALS AND METHODS}

The performed field experiments were carried out in 2016, 2017 in Domaszék and in 2018 in Ásotthalom in South-East Hungary, on moderately alkaline sandy soil. The change of site was necessary due to an intense infection by white grubs detected during the second crop year.
Soil samples were randomly taken from a depth of 0-30 cm from the experimental fields before planting. As a next step, the composite soil samples were analyzed at Hódmezővásárhely Soil Testing Laboratory for the determination of the selected physical-chemical properties of the soil (Table 1).

Results of soil analysis in Domaszék and Ásotthalom

\begin{tabular}{lccccccccc}
\hline Site & $\mathrm{pH}-\mathrm{KCl}$ & $\begin{array}{c}\text { Total salt } \\
\mathrm{m} \mathrm{per} \mathrm{m} \%\end{array}$ & $\begin{array}{c}\text { Soil plasticity } \\
\mathrm{K}_{\mathrm{A}}\end{array}$ & $\begin{array}{c}\mathrm{CaCO}_{3} \\
\mathrm{~m} \text { per m \% }\end{array}$ & $\begin{array}{c}\text { Humus } \\
\text { m per m \% }\end{array}$ & $\begin{array}{c}\mathrm{P}_{2} \mathrm{O}_{5} \\
\mathrm{~K}_{2} \mathrm{O}\end{array}$ & $\begin{array}{c}\mathrm{Na} \\
\mathrm{mg} \mathrm{kg}^{-1}\end{array}$ \\
\hline Domaszék & 7.70 & 0.04 & 29 & 3.46 & 0.94 & 824 & 145 & 15.6 & 55 \\
Ásotthalom & 7.56 & 0.02 & 29 & 3.03 & 0.65 & 308 & 80 & 7.9 & 15 \\
\hline
\end{tabular}

The experimental setup was Randomised Complete Block Design (RCBD) with four repetitions. The experiments consisted of four plant spacing setups (row distance x plant-to-plant distance): $80 \mathrm{~cm} \mathrm{x} 20 \mathrm{~cm}, 80$ $\mathrm{cm} \times 30 \mathrm{~cm}, 100 \mathrm{~cm}$ x $20 \mathrm{~cm}, 100 \mathrm{~cm}$ x $30 \mathrm{~cm}$. The four population densities in numbers of plants per hectare are shown in Table 2. The certified Hungarian variety 'Ásotthalmi-12' provided the plant material in all experiments. The sweet potato cuttings (slips) were derived from the Bivalyos Tanya Family Farm and the planting was performed on $29^{\text {th }}$ May 2016, $4^{\text {th }}$ June 2017 and $31^{\text {th }}$ May 2018, with cca. 450 slips on the whole experimental area of $150 \mathrm{~m}^{2}$. Spring tillage was followed by soil disinfection on one occasion before planting. The cuttings were planted manually with a dibble. In 2016 and 2017, for nutrient supply, the fertilizer Volldünger ${ }^{\circledR}$ Linz Classic (14-7-21) was applied. In 2018, the fertilizers were applied through an irrigation system with variable NPK rates in various development stages of the crop. The NPK fertilizers were used in the forms of calcium ammonium nitrate $(27 \% \mathrm{~N})$, superphosphate $\left(20 \% \mathrm{P}_{2} \mathrm{O}_{5}\right)$ and potassium sulphate $\left(51 \% \mathrm{~K}_{2} \mathrm{O}\right)$, respectively. Weed control was done manually on the whole experimental area in all years. The storage roots of the experimental plots were harvested in bulk per plot and the mean yields per plant were calculated in each year. The sweet potato storage roots were harvested after five months each year using digging fork accordingly. The corresponding yields in tons $\mathrm{ha}^{-1}$ and yield per plant were determined and analyzed. The experimental plots were harvested on $9^{\text {th }}$ and $15^{\text {th }}$ October 2016, on $15^{\text {th }}$ October 2017 and on $29^{\text {th }}$ of September 2018. The harvesting was done when the vines of $90 \%$ of the plant population in each plot turned yellow or senesced and the tubers reached maturity as shown by cracking of the soil above the tuber.

Table 2

Plant population density

\begin{tabular}{lc}
\hline Spacing & Plants ha $^{-1}$ \\
\hline $80 \mathrm{~cm} \times 20 \mathrm{~cm}$ & 62,500 \\
$80 \mathrm{~cm} \times 30 \mathrm{~cm}$ & 41,600 \\
$100 \mathrm{~cm} \times 20 \mathrm{~cm}$ & 50,000 \\
$100 \mathrm{~cm} \times 30 \mathrm{~cm}$ & 33,333 \\
\hline
\end{tabular}

\section{Statistical analysis}

Data were subjected to analysis of variance (ANOVA). Significant differences between treatment means were separated using least significant difference (LSD $5 \%$ ) test at 5\% level of significance (Harnos és Ladányi, 2005).

\section{RESULTS AND DISCUSSION}

Effect of plant density on the yield per plant (gram)

The analysis of variance revealed that planting density significantly $(\mathrm{P}<0.05)$ affected the average yield of tuberous roots. In 2017, the yields achieved with $100 \mathrm{~cm} \times 30 \mathrm{~cm}$ plant density compared to the other densities were significantly different (Table. 3). Figure 1 shows that the highest yield per plant was achieved with the $100 \mathrm{~cm} \times 30 \mathrm{~cm}$ setup in 2016 (980 g) and in 2017 (390 g). In 2018, the $80 \mathrm{~cm} \times 30 \mathrm{~cm}$ gave the best result per plant $(930 \mathrm{~g})$. Results showed that closer plant density decreased the yield per plant.

Figure 1: Effect of plant density on yield per plant (gram)

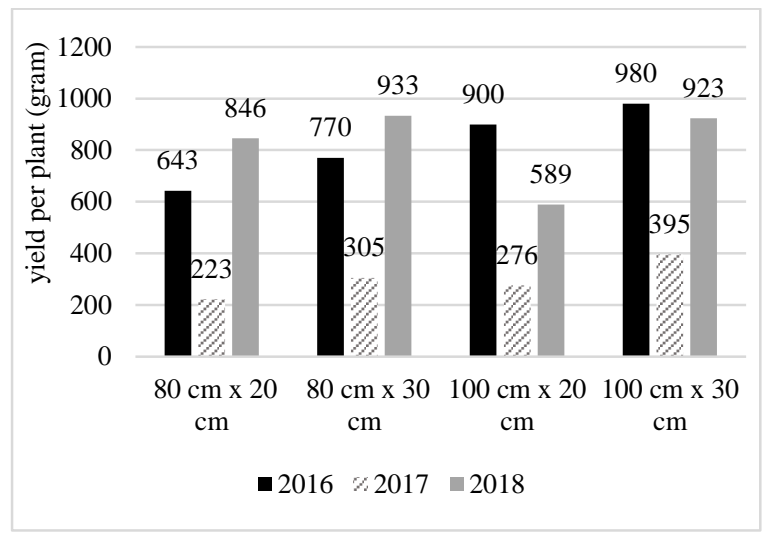

Notes: unit of measure is gram per plant, LSD $(0.05)=$ Least Significant Difference at $5 \%$ level $\quad 2017=L S D_{5 \%}=0,07$ 
Analysis of variance table in 2017

\begin{tabular}{|c|c|c|c|c|c|c|}
\hline \multicolumn{7}{|l|}{ Total } \\
\hline Groups & Pieces & Data & Average & Variance & Standard deviation & \\
\hline $80 \mathrm{~cm} \times 20 \mathrm{~cm}$ & 4 & 892 & 223 & 1258 & 35.46 & \\
\hline $80 \mathrm{~cm} \mathrm{x} 30 \mathrm{~cm}$ & 4 & 1218 & 304.5 & 3644.33 & 60.36 & \\
\hline $100 \mathrm{~cm} \times 20 \mathrm{~cm}$ & 4 & 1103 & 275.75 & 2674.25 & 51.71 & \\
\hline $100 \mathrm{~cm} \mathrm{x} 30 \mathrm{~cm}$ & 4 & 1580 & 395 & 2300 & 47.95 & \\
\hline \multicolumn{7}{|l|}{ Analysis of variance } \\
\hline Factors: & SS & df & MS & $\mathrm{F}$ & $\mathrm{p}$ & F critic \\
\hline Between the group & 62246.18 & 3 & 20748.72 & 8.40 & 0.002 & 3.49 \\
\hline Inside the group & 29629.75 & 12 & 2469.14 & & & \\
\hline Total: & 91875.93 & 15 & & & & \\
\hline
\end{tabular}

Note: data marked with the same letter in the same column are not significantly different at the significance level of 0.05

Effect of plant density on storage root yield $\left(\mathrm{t} \mathrm{ha}^{-1}\right)$

Figure 2 shows that the best results at hectare level were obtained with planting at $80 \mathrm{~cm} \times 20 \mathrm{~cm}$ in each year. Increasing plant density from 3.33 plants $\mathrm{m}^{-2}(100$ $\mathrm{cm} \times 30 \mathrm{~cm})$ to higher levels of 6.25 plants $\mathrm{m}^{-2}(80 \mathrm{~cm}$ $\mathrm{x} 20 \mathrm{~cm}$ ) increased the production of total storage root yields.

The population density of 62,500 plants ha $^{-1}$ with planting at $80 \mathrm{~cm} \times 20 \mathrm{~cm}$ produced the highest yield of $52.8 \mathrm{t} \mathrm{ha}^{-1}$ in 2018 , followed by $45.6 \mathrm{t} \mathrm{ha}^{-1}$ in 2016 , and $13.93 \mathrm{t} \mathrm{ha}^{-1}$ in 2017. The differences between the average yields in 2016 and 2017 were significant $(\mathrm{p}<0.001)$.

Comparing the highest tons $\mathrm{ha}^{-1}$ results to those achieved with the plant spacing setups resulting in the highest yield per plant, the differences can be even 13 or 14 tons at hectare level like in 2016 and 2018, respectively. At a generally low yield level as achieved in 2017 , the difference is well below 1 ton $\left(0.77 \mathrm{t} \mathrm{ha}^{-1}\right)$.

Figure 2: Effect of plant density on storage root yield (t ha'

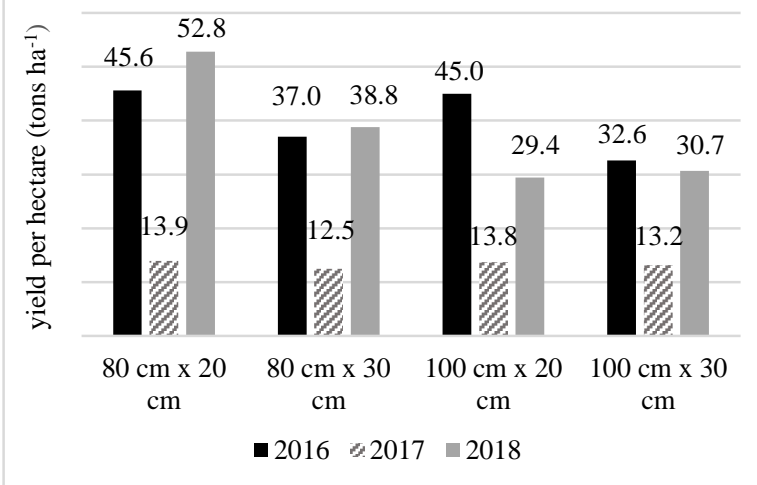

Note: unit of measure is tons per hectare, $P \leq 0.05$.

\section{CONCLUSIONS}

This work reveals that higher plant density increases the total yield per hectare but decreases the yield per plant in sweet potato. Alvin et al. (2007) also reported that with increasing plant density, the yield of sweet potato increased. Ojikpong et al. (2007) described that maximum yields are obtained at a closer spacing. Krochmal-Marczak and Sawicka (2010) detected high genotype-dependency regarding the optimal in-row distance. The genotype-independent evaluation of their experiments, however, showed a medium size of in-row distance $(40 \mathrm{~cm})$ resulting in higher yields compared to both the lower $(30 \mathrm{~cm})$ and the higher $(50 \mathrm{~cm})$ ones.

The results of the experiments described here also indicate significant differences in storage root yields per hectare, the highest value being recorded at $80 \mathrm{~cm}$ x $20 \mathrm{~cm}$ plant density in each year. Comparisons with the yields of the setups resulting the highest yield per plant showed differences of 13-14 tons at a high general yield level, while the difference was negligible (0.77 tons) if the general yield level was low. Simple economic evaluations considering costs and incomes (data not shown) also confirm the beneficial effects of increased plant density. Further experiments are needed to evaluate the influence of plant density on the size and uniformity of tubers thus determining marketability.

It appears also that different yield parameters favour different population densities. It is therefore important to increase production and productivity of the crop by adopting different agronomic practices that include determination of optimum plant density.

\section{ACKNOWLEDGEMENTS}

The authors express their sincere thanks to the Bivalyos Tanya Family Farm, to the Hódmezővásárhely Soil Testing Laboratory and to their families. 


\section{REFERENCES}

Alvin, J. B.-Mitchell, P. D.-Copas, M. E.-Drilias, M. J. (2007) Evaluations of the effect of density on potato yield and tuber size distribution. Crop Sci 47: 2462-2472.

Bavec, F.-Bavec, M. (2006): Sweet potato. In: Bavec, F., Bavec, M. Organic production and use of alternative crops. CRC Press, Taylor \& Francis Group. Pp. 189-200. 214 p.

Berényi, B.-Szabó, L. (2001): Növénytermesztés trópusokonszubtrópusokon, Mezőgazdaság Szaktudás Kiadó, Budapest, 72 p.

Clark, C. (2013): Cultivation and storage. In: Clark, C.A., Ferrin, D.M., Smith, T.P., Holmes, G.J. (eds.): Compendium of sweet potato disease, pests, and disorders. Second edition. APS Press, St. Paul, Minnesota. Pp. 4-7.

Coolong, T.-Seebold, K.-Bessin, R.-Woods, T.-Fannin, S. (2012) Sweetpotato production for Kentucky. ID-195. University of Kentucky Cooperative Extension Service, Lexington, KY 40506.

Harnos, Zs.-Ladányi, M. (2005): Biometria agrártudományi alkalmazásokkal, Aula Kiadó Kft. Budapesti Corvinus Egyetem, pp. 330

Horváth, L. (1991a): A batáta és termesztése: Az édesburgonya Magyarországon. Kertészet és Szőlészet 40(15): 16-17.

Horváth,. L. (1991b): A batáta Magyarországon: Védelem, tárolás. Kertészet és Szőlészet 40 (16): 16.

Horváth, L. (1991c): A batáta szaporítása. Kertészet és Szőlészet 40 (21): 7 .

Http1:http://magyarmezogazdasag.hu/2016/01/06/hazankbantermesztheto-batata

Http2:http://media.wix.com/ugd/a6aecc_7311b235e08a49cf817a3b d7de7bb6fe.pdf

Kay, D.E. (1973): Crop and product Digest 2: Root crops, Tropical Product Institute, London. pp. 245.

Krochmal-Marczak, B.-Sawicka, B. (2010): Variability of economic characteristics of Ipomoea batatas L. (Lam.) in the conditions of cultivation under cover. Annales Universitatis Mariae CurieSklodowska Lublin - Polonia 65(4): 29-40.
Negeve, J. M.-Hahn, S. K.-Bouwkamp, J. C. (1992): Effect of altitude and environments on sweet potato yield in Cameroon. Trop. Agricultural. Trinidad 69: 43-48.

Norman, A. G. (1963): Competition among crop and pasture plants. Adv in Agron. 15: 1- 114.

North Carolina Sweet Potato Commission (NCSPC) (2015): Growing sweet potatoes in North Carolina: planting. [Online]. Available from http://www.ncsweetpotatoes.com/sweet-potatoindustry/growing-sweet-potatoes-in-north-carolina/planting/ [accessed 1 May 2015] Google Scholar

Ojikpong, T. O.-Okpara, D. A.-Munoneke, C. O. (2007): Effect of plant spacing and sowing date of sassame production in south Eastern Nigeria. The Nigerian Agricultural Journal 38:12-21.

OMAFRA (2010): Vegetable production recommendations 20102011. Publication 363, Ontario Ministry of Agriculture, Food and Rural Affairs, 1 Stone Road West, Guelph, ON N1G 4Y2, Canada Google Scholar

Onunka, N. A.-Nwokocha, H. N. (2008): Response of sweetpotato (Ipomoea batatas (L) Lam) to different levels of nitrogen fertilization in a tropical ultisol of South Eastern Nigeria 2 (2) 42-46.

Singh, N. P. -Singh, R. A. (2002): Scientific crop production, X press Graphics, Delhi-28, 1st ed., India sweet potato yield in Cameroon. Trop. Agricultural. Trinidad 69: 43-48.

Teow, C. C.-Truong, V. D.-McFeeters, R. F.-Thompson, R. L.Pecota, K. V.-Yencho, G. C. (2007): Antioxidant activities, phenolic and $\beta$-carotene contents of sweet potato genotypes with varying flesh colours. Food Chem 103:829-838.

Yoshinaga, M.-Yamakawa, O.-Nakatani M. (1999): Genotypic diversity of anthocyanins content and composition in purplefleshed sweetpotato. Breeding Sci 49: 43-47. 